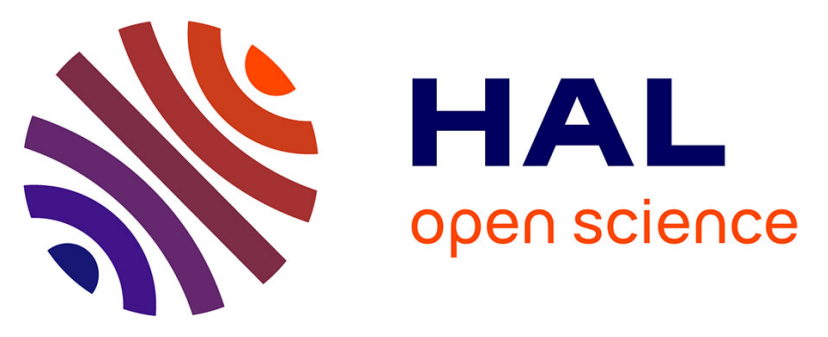

\title{
Oxygen Evolution Reaction Activity and Stability Benchmarks for Supported and Unsupported $\mathrm{IrO} \mathrm{x}$ Electrocatalysts
}

\author{
Camila Daiane Ferreira da Silva, Fabien Claudel, Vincent Martin, Raphaël \\ Chattot, Sofyane Abbou, Kavita Kumar, Ignacio Jiménez-Morales, Sara \\ Cavaliere, Deborah Jones, Jacques Rozière, et al.
}

\section{To cite this version:}

Camila Daiane Ferreira da Silva, Fabien Claudel, Vincent Martin, Raphaël Chattot, Sofyane Abbou, et al.. Oxygen Evolution Reaction Activity and Stability Benchmarks for Supported and Unsupported IrO x Electrocatalysts. ACS Catalysis, 2021, 11 (7), pp.4107-4116. 10.1021/acscatal.0c04613 . hal03195339

\author{
HAL Id: hal-03195339 \\ https://hal.science/hal-03195339
}

Submitted on 11 Apr 2021

HAL is a multi-disciplinary open access archive for the deposit and dissemination of scientific research documents, whether they are published or not. The documents may come from teaching and research institutions in France or abroad, or from public or private research centers.
L'archive ouverte pluridisciplinaire HAL, est destinée au dépôt et à la diffusion de documents scientifiques de niveau recherche, publiés ou non, émanant des établissements d'enseignement et de recherche français ou étrangers, des laboratoires publics ou privés.

\section{(ㅇ)(1) $\$$}

Distributed under a Creative Commons Attribution - NonCommercial - NoDerivatives 44.0 


\section{Oxygen Evolution Reaction Activity and Stability}

\section{Benchmarks for Supported and Unsupported $\mathrm{IrO}_{\mathrm{x}}$}

\section{Electrocatalysts}

Camila Daiane Ferreira da Silva, ${ }^{1,2,}, \gamma, \alpha$ Fabien Claudel, ${ }^{1, \gamma}$ Vincent Martin, ${ }^{1}$ Raphaël

Chattot, ${ }^{1}$ Sofyane Abbou, ${ }^{1}$ Kavita Kumar, ${ }^{1}$ Ignacio Jiménez-Morales, ${ }^{3}$ Sara Cavaliere, ${ }^{3}$

Deborah Jones, ${ }^{3}$ Jacques Rozière, ${ }^{3}$ Lluís Solà-Hernandez, ${ }^{4}$ Christian Beauger, ${ }^{4}$ Marco

Faustini, ${ }^{5}$ Jennifer Peron, ${ }^{6}$ Bruno Gilles, ${ }^{7}$ Thierry Encinas, ${ }^{8}$ Laurent Piccolo, ${ }^{9}$ Fabio Henrique Barros de Lima ${ }^{2}$, Laetitia Dubau, ${ }^{1}$ Frédéric Maillard $* 1$

1. Univ. Grenoble Alpes, Univ. Savoie Mont Blanc, CNRS, Grenoble INP, LEPMI, 38000, Grenoble, France

2. São Carlos Institute of Chemistry, University of São Paulo, Av. Trabalhador Saocarlense, 400, São Carlos, SP, Brazil

3. ICGM, Univ. Montpellier, CNRS, ENSCM, Montpellier, France

4. MINES ParisTech, PSL University, Center for Processes, Renewable Energy and Energy Systems (PERSEE), CS 10207, rue Claude Daunesse, F-06904, Sophia Antipolis, Cedex, France

5. Sorbonne Université, CNRS, Collège de France, UMR 7574, Chimie de la Matière Condensée de Paris, F-75005 Paris, France 
6. Université de Paris, ITODYS, CNRS, UMR 7086, 15 rue J-A de Baïf, F-75013 Paris, France

7. Univ. Grenoble Alpes, CNRS, Grenoble INP, SIMAP, 38000 Grenoble, France

8. Univ. Grenoble Alpes, Grenoble INP, CMTC, 38000 Grenoble, France

9. Univ Lyon, Université Claude Bernard - Lyon 1, CNRS, IRCELYON - UMR 5256, 2 Avenue Albert Einstein, F-69626 Villeurbanne CEDEX, France 


\section{ABSTRACT}

Advanced materials are needed to meet the requirements of devices designed for harvesting and storing renewable electricity. In particular, polymer electrolyte membrane water electrolyzers (PEMWEs) could benefit from a reduction in the size of the iridium oxide $\left(\mathrm{IrO}_{\mathrm{x}}\right)$ particles used to electrocatalyze the sluggish oxygen evolution reaction (OER). To verify the validity of this approach, we built a library of 18 supported and unsupported $\mathrm{IrO}_{\mathrm{x}}$ catalysts and established their stability number ( $S$-number) values using inductively-coupled plasma mass spectrometry and electrochemistry. Our results provide quantitative evidence that (i) supported $\mathrm{IrO}_{\mathrm{x}}$ nanocatalysts are more active towards the OER but less stable than unsupported micrometer-sized catalysts, e.g. commercial $\mathrm{IrO}_{2}$ or porous $\mathrm{IrO}_{\mathrm{x}}$ microparticles; (ii) tantalum-doped tin oxides (TaTO) used as supports for $\mathrm{IrO}_{\mathrm{x}}$ nanoparticles are more stable than antimony-doped tin oxides (ATO) and carbon black (Vulcan XC72); (iii) thermal annealing under air atmosphere yields depreciated OER activity but enhanced stability; (iv) the beneficial effect of thermal annealing holds both for microand nano- $\mathrm{IrO}_{\mathrm{x}}$ particles, and leads to one order of magnitude lower Ir atom dissolution rate with respect to non-annealed catalysts; (v) the best compromise between OER activity and stability was obtained for unsupported porous $\mathrm{IrO}_{\mathrm{x}}$ microparticles after thermal annealing under air at $450^{\circ} \mathrm{C}$. These insights provide guidance on which material classes and strategies are the most likely to increase sustainably the OER efficiency while contributing to diminish the cost of PEMWE devices.

KEYWORDS: proton exchange membrane water electrolyzer; oxygen evolution reaction; doped tin oxide; iridium oxide nanoparticles; $S$-number. 


\section{INTRODUCTION}

The worldwide development of renewable energies is essential to meet the ever-increasing energy demand and to limit air pollution issues associated with the use of fossil fuels. According to the Statistical Review of World Energy published by British Petroleum, ${ }^{1}$ the share of renewables in the world energy consumption rose to an unprecedented value of $5 \%$ in 2019 , currently accounting for $10.4 \%$ of the world electricity production. However, large-scale energy storage units are required to counterbalance the intermittency of renewable energy sources. Pumped hydroelectricity, which relies on the transfer of water between two reservoirs located at different altitudes, is the most efficient technology (70-85\%) to store electricity at power-grid proportions. The efficiency of lithium-ion batteries is close to $85-90 \%$. However, their high price per gigawatt hour (currently close to $150,000,000 €^{2}$ ), their insufficient lifespan and the scarcity/lack of purity of the deposits of lithium on Earth limit their usage to consumer electronics (laptops, tablets and cell phones) and to electric or hybrid electric vehicles. Power-to-gas, in particular power-to-hydrogen, is the third option. Water electrolyzers produce molecular hydrogen $\left(\mathrm{H}_{2}\right)$ at an efficiency of $c a .65 \%$ using surplus of renewable electricity generated at off-peak times. Alkaline water electrolysis is a reliable, long-lifetime technology based on abundant elements in the Earth's crust (e.g. nickel) ${ }^{3}$. In contrast, proton-exchange membrane water electrolyzers (PEMWEs) electrodes use scarce and costly platinum group metals (PGMs) but only such devices are able to meet the requirements associated with renewable energies: large amplitude (100-300\% of the nominal current), rapid $(<30$ seconds) and frequent variations in the power applied to the water electrolysis cells ${ }^{4-6}$. The Achille's heel of PEMWEs is their high cost per $\mathrm{kW}$, mostly associated with that of electricity but also of constituting materials (PGM content in the electrodes, polymer electrolyte membrane, titanium in the porous transport layers, bipolar plates made of 
stainless steel). Decreasing the size and thereby the loading of the iridium oxide $\left(\operatorname{IrO} \mathrm{x}_{\mathrm{x}}\right)$ particles used to electrocatalyze the anodic oxygen evolution reaction (OER) is thus an appealing strategy to both reduce the cost of this technology and limit the geological pressure on iridium (gold and platinum are 40-fold and 10-fold more abundant than iridium, respectively ${ }^{7}$ ). However, the GibbsThompson effect, ${ }^{8-10}$ which controls the electrochemical stability of nanomaterials, casts a doubt on the viability of this approach.

To tackle these issues, we benchmarked commercial materials (unsupported $\mathrm{IrO}_{2}, \mathrm{Ir} / \mathrm{C}$ ), unsupported porous iridium oxide $\left(\mathrm{IrO}_{\mathrm{x}}\right)$ microparticles, and $\mathrm{IrO}_{\mathrm{x}}$ nanoparticles $(\mathrm{NPs})$ supported on carbon black or on doped tin oxide aerogels (AG)/nanofibers (NFs). These were imaged before and after electrochemical testing by transmission electron microscopy (TEM) or identical-location transmission electron microscopy (IL-TEM). By coupling electrochemistry with inductivelycoupled mass spectrometry (ICP-MS), we assessed their stability number ( $S$-number) values in a H-cell with separated anodic and cathodic compartments. Our findings thus provide practical strategies to design a more efficient and durable new generation of OER nanocatalysts.

\section{RESULTS AND DISCUSSION}

Synthesis, characterization and initial OER activity of supported and unsupported IrO $\mathrm{I}_{x}$ catalysts

Figure 1 schematically describes the various catalysts used in this study (TEM images, base cyclic voltammograms and OER polarization curves can be found in Figure S1, and physicochemical characteristics can be found in Figure S2 and Table S1). These are referred to as $\mathrm{IrO}_{\mathrm{x}} /$ support-X-Y, where $\mathrm{IrO}_{\mathrm{x}}$ represent $\mathrm{NPs} c a .1 .4 \mathrm{~nm}$ in size prepared using a highly reproducible polyol synthesis method, supports are Vulcan XC72 (C), antimony- or tantalum- 
doped tin oxide (ATO and TaTO, respectively) or a commercial $\mathrm{IrO}_{2}$ powder ( $\mathrm{IrO}_{2}$ comm.), and $X$ and $Y$ provide information on the degree of doping of the tin oxide $\left(\mathrm{SnO}_{2}\right)$ matrix (in at. \%), its morphology (AG or NFs) and/or the temperature at which the electrocatalyst was thermallyannealed under air atmosphere. Four different categories of catalysts can be distinguished:

- Carbon-supported Ir or $\mathrm{IrO}_{\mathrm{x}} \mathrm{NPs}$, including a commercial $\mathrm{Ir} / \mathrm{C}(\mathrm{Ir} / \mathrm{C}$ comm. $)$ and $\mathrm{IrO} \mathrm{x}_{\mathrm{x}} \mathrm{NPs}$ deposited onto Vulcan $\mathrm{XC} 72\left(\mathrm{IrO}_{\mathrm{x}} / \mathrm{C}\right)$;

- $\mathrm{IrO}_{\mathrm{x}} \mathrm{NPs}$ deposited onto an ATO aerogel ( $\left.\mathrm{IrO}_{\mathrm{x}} / \mathrm{ATO}-10-\mathrm{AG}\right)$, onto ATO nanofibers (IrOx/ATO-10-NFs), or onto a TaTO aerogel $\left(\mathrm{IrO}_{\mathrm{x}} / \mathrm{TaTO}-2.5-\mathrm{AG}, \mathrm{IrO}_{\mathrm{x}} / \mathrm{TaTO}-5-\mathrm{AG}\right.$ and $\left.\mathrm{IrO}_{\mathrm{x}} / \mathrm{TaTO}-18-\mathrm{AG}\right)$;

- Unsupported $\mathrm{IrO}_{\mathrm{x}}$ electrocatalysts, including $\mathrm{IrO}_{2}$ comm., $\mathrm{IrO}_{2}$ comm. after thermal annealing under air atmosphere $\left(\mathrm{IrO}_{2}\right.$ comm. $-450^{\circ} \mathrm{C}$ and $\mathrm{IrO}_{2}$ comm. $\left.-800^{\circ} \mathrm{C}\right), \mathrm{IrO}_{\mathrm{x}} / \mathrm{C}$ after thermal annealing under air $\left(\mathrm{IrO}_{x} / \mathrm{C}-450^{\circ} \mathrm{C}\right.$ and $\left.\mathrm{IrO}_{x} / \mathrm{C}-600^{\circ} \mathrm{C}\right), \mathrm{IrO}_{\mathrm{x}} \mathrm{NPs}$ deposited on $\mathrm{IrO}_{2}$ comm. $\left(\mathrm{IrO}_{\mathrm{x}} / \mathrm{IrO}_{2}\right.$ comm. $)$, porous $\mathrm{IrO}_{\mathrm{x}}$ microparticles after thermal annealing under air atmosphere at different temperatures (porous $\operatorname{Ir} \mathrm{O}_{\mathrm{x}}-400^{\circ} \mathrm{C}$, porous $\operatorname{IrO} \mathrm{x}-450^{\circ} \mathrm{C}$, porous $\operatorname{IrO} \mathrm{x}-500^{\circ} \mathrm{C}$ and porous $\left.\mathrm{IrO}_{\mathrm{x}}-800^{\circ} \mathrm{C}\right)$. Note that $\mathrm{IrO}_{\mathrm{x}} / \mathrm{C}-450^{\circ} \mathrm{C}$ and $\mathrm{IrO}_{\mathrm{x}} / \mathrm{C}-600^{\circ} \mathrm{C}$ fall in the unsupported $\mathrm{IrO}_{\mathrm{x}}$ electrocatalysts category as a result of the gasification of the Vulcan support during thermal-annealing in $\mathrm{O}_{2}$ atmosphere;

- Polycrystalline Ir thin-film ( $\left.\operatorname{Ir}_{\mathrm{pc}}\right)$. 


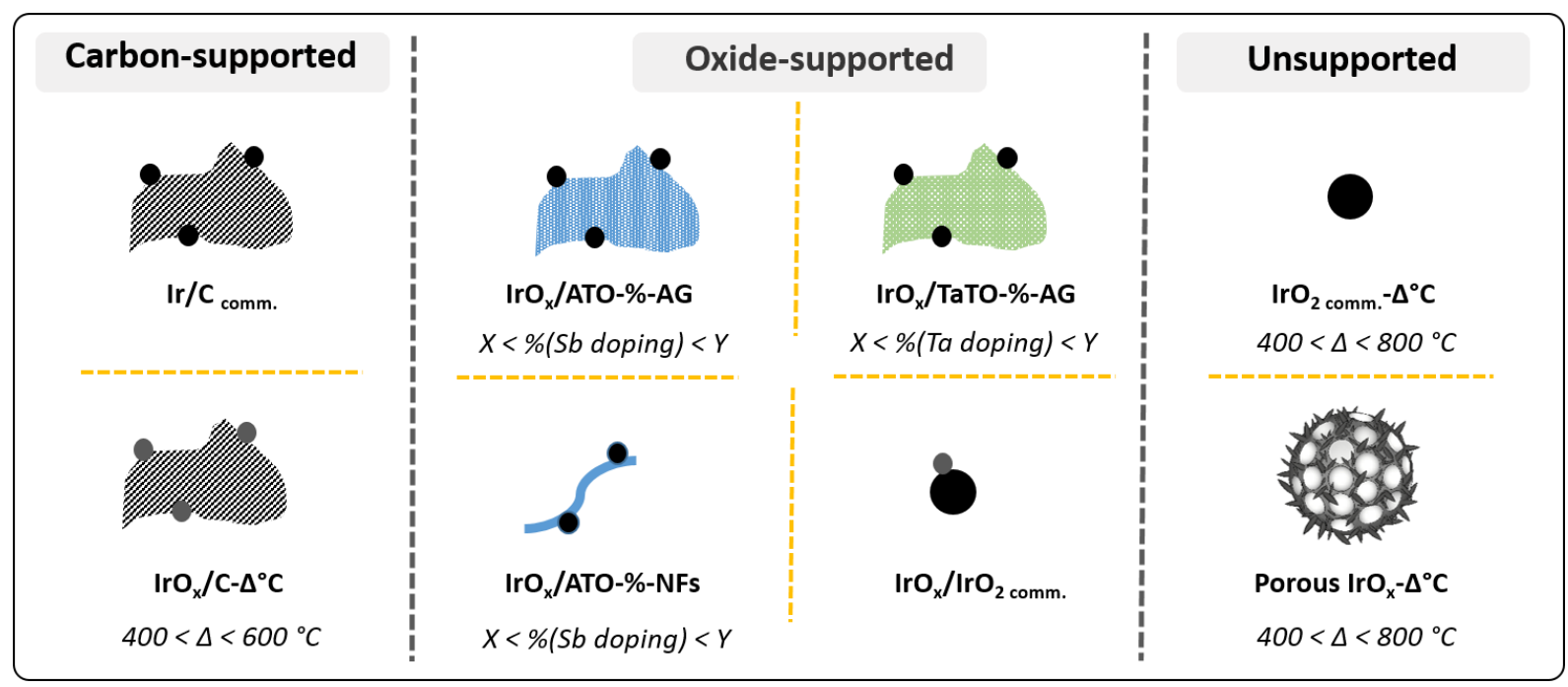

Figure 1. Scheme of the library of materials constituted to benchmark the OER activity and the stability of the different $\mathrm{IrO}_{\mathrm{x}}$ nano-/micro-particles. AG and NFs stand for aerogel and nanofibers, respectively.

Insights into the oxidation state of Ir surface atoms after the electrochemical conditioning (100 cycles between 0.05 and $1.40 \mathrm{~V}$ vs. RHE) are provided by the base cyclic voltammograms recorded in $0.05 \mathrm{M} \mathrm{H}_{2} \mathrm{SO}_{4}$ (Figure $\mathbf{S 1}$ ). Indeed, the presence of $\operatorname{Ir}(+\mathrm{III}) / \mathrm{Ir}(+\mathrm{IV})$ redox peaks at $c a$. $0.95 \mathrm{~V} v s$. RHE shows that mixed Ir oxidation states co-exist in some catalysts, notably the nonthermally annealed, supported ones ${ }^{11-12}$. The presence of a potential region where protons are underpotentially deposited $(E<0.3 \mathrm{~V} v s$. RHE) in the CVs also suggests that some surface Ir atoms remained metallic after the electrochemical conditioning ${ }^{13}$. This trend is more pronounced for supported $\mathrm{IrO}_{\mathrm{x}}$ nanocatalysts than for unsupported ones but it tends to vanish upon thermal annealing at $T>400{ }^{\circ} \mathrm{C}$ under air atmosphere, in line with the formation of a tetragonal $\mathrm{IrO}_{2}$ structure (see in situ X-ray diffractograms of $\mathrm{IrO}_{2}$ comm. in Figure S3). Note that electrochemical oxidation of Ir nanoparticles in $\mathrm{H}_{2} \mathrm{SO}_{4}$ proved to be faster than in $\mathrm{HClO}_{4}$, hence influencing both the oxidation state of Ir surface atoms after the conditioning step and their OER activity ${ }^{14}$. 
Figure 2 illustrates the kinetic gain provided by decreasing the $\mathrm{IrO}_{\mathrm{x}}$ particle size to nanometer dimensions. For all supported nanocatalysts, the mass-normalized OER activities $\left(j\right.$ mass, $\mathrm{A} \mathrm{g}^{-1}$ Ir $)$ exceeded $100 \mathrm{~A} \mathrm{~g}^{-1}$ Ir at $1.51 \mathrm{~V}$ vs. RHE and $500 \mathrm{~A} \mathrm{~g}^{-1}$ Ir at $1.55 \mathrm{~V} v s$. RHE (Figure S4), and a 10fold enhancement of the OER mass activity over the commercial $\mathrm{IrO}_{2}$ catalyst was measured for the best electrocatalysts $\left(\mathrm{IrO}_{\mathrm{x}} / \mathrm{C}\right.$ and $\left.\mathrm{IrO}_{\mathrm{x}} / \mathrm{ATO}-10-\mathrm{NFs}\right)$. As shown by Equation 1, the mass-

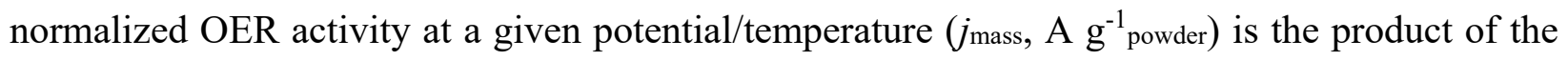
turnover frequency of the OER active sites in the same experimental conditions (TOF, electrons site $^{-1} \mathrm{~s}^{-1}$ ), the gravimetric active site density for the OER (ASD, mol $\mathrm{g}^{-1}$ powder), and the Faraday constant $F\left(\mathrm{~A} \mathrm{~s} \mathrm{~mol}^{-1}\right)$ :

$$
j_{\text {mass }}=\mathrm{TOF} \times \mathrm{ASD} \times \mathrm{F}
$$

Former studies have established that mixed Ir oxidation states coexist in $\mathrm{IrO}_{\mathrm{x}} \mathrm{NPs}$ produced by the polyol route ${ }^{15-18}$. Moreover, the oxidation degree of the Ir surface atoms strongly depends on the chemical nature of the support ${ }^{15-16,18}$. Oh et al. ${ }^{18}$ first reported that $\mathrm{IrO}_{\mathrm{x}}$ nanoparticles are, in average, more metallic when supported on ATO vs. Vulcan XC72. As shown by Claudel et al., ${ }^{15}$ this trend persists over time: $\mathrm{IrO}_{\mathrm{x}}$ nanoparticles supported onto ATO are less oxidized than $\mathrm{IrO}_{\mathrm{x}}$ nanoparticles arising from the same colloidal solution but supported on Vulcan XC72, even after 30,000 potential cycles between 1.2 and $1.6 \mathrm{~V}$ vs. RHE. Similar effect was recently reported for TaTO supports by Abbou et al. ${ }^{16}$. The authors also evidenced an effect of the concentration of Ta on the oxidation degree of Ir surface atoms and of the age of the catalytic suspension. Because the presence of $\operatorname{Ir}(+\mathrm{III}) / \mathrm{Ir}(+\mathrm{V})$ species plays a beneficial role for the rate of both the Ir cation red $-o x$ mechanism ${ }^{11,19-23}$ and the $\mathrm{O}$ anion $r e d$ - ox mechanism, ${ }^{24}$ a large fraction of the electrocatalytic 
enhancement thus arises from the fact that the $\mathrm{IrO}_{x} \mathrm{NPs}$ are sub-stoichiometric. This hypothesis is confirmed by (i) Figure 2 showing that metallic $\operatorname{Ir}\left(\operatorname{Ir}_{p c}\right.$ and $\left.\operatorname{Ir} / \mathrm{C}\right)$ and $\mathrm{IrO}_{\mathrm{x}} \mathrm{NPs}$ feature higher charge-normalized OER activities at 1.51 and $1.55 \mathrm{~V} v s$. RHE $\left(j_{\text {spec }}\right.$ in $\mathrm{mA} \mathrm{mC} \mathrm{m}^{-1}$, see calculation mode in Supporting Information), and by (ii) the fact that the deposition of $\mathrm{IrO}_{\mathrm{x}} \mathrm{NPs}$ onto the commercial $\mathrm{IrO}_{2}\left(\mathrm{IrO}_{\mathrm{x}} / \mathrm{IrO}_{2 \text { comm. }}\right)$ leads to a nearly 2 -fold gain in OER charge-normalized activity compared to the mother $\mathrm{IrO}_{2}$ comm.

Obviously, a large fraction of the OER mass activity enhancement is also due to the decrease of the $\mathrm{IrO}_{\mathrm{x}}$ particle size. To provide evidence for this, we refer to the results obtained on the $\mathrm{IrO}_{2}$ comm $-450^{\circ} \mathrm{C}$, porous $\mathrm{IrO}_{\mathrm{x}}-450^{\circ} \mathrm{C}$, and $\mathrm{IrO}_{\mathrm{x}} / \mathrm{C}-450^{\circ} \mathrm{C}$ samples. Because these materials were exposed to nearly-identical thermal annealing conditions (temperature/atmosphere), the Ir surface atoms feature similar oxidation state in the three catalytic materials (see Figure S5); hence the differences in OER activity mostly relate to the differences in particle sizes. As shown by Figure 1, (i) the commercial $\mathrm{IrO}_{2}$ catalyst contains a mixture of small and large $(100 \mathrm{~nm})$ solid particles; (ii) porous $\mathrm{IrO}_{\mathrm{x}}$ catalysts feature an average crystallite size of $c a .9 \mathrm{~nm}$ arranged into spheroidal porous particles with size $>1 \mu \mathrm{m}$ and pores diameters of $c a \cdot 200-300 \mathrm{~nm}{ }^{25}$ and, (iii) even after gasification of the carbon black support upon thermal annealing under air, the $\mathrm{IrO}_{\mathrm{x}} / \mathrm{C}-450^{\circ} \mathrm{C}$ catalyst features small $\mathrm{IrO}_{x} \mathrm{NPs}(6-8 \mathrm{~nm})$, aerogel-type structure and open porosity. It is clear from Figure 2 that the charge-normalized OER activities of the three catalysts are similar, thus supporting our prime hypothesis that all Ir surface atoms feature similar oxidation state. However, the OER mass activity varies as $\mathrm{IrO}_{\mathrm{x}} / \mathrm{C}-450^{\circ} \mathrm{C}>$ porous $\mathrm{IrO}_{\mathrm{x}}-450^{\circ} \mathrm{C}>\mathrm{IrO}_{2}$ comm. $-450^{\circ} \mathrm{C}$, i.e. it is inversely proportional to the $\mathrm{IrO}_{\mathrm{x}} \mathrm{NP}$ size. 
Let us now underline that TOF and ASD are often interrelated parameters (e.g. a change in the Ir oxidation state usually translates into a change in crystallographic structure/ASD value). For example, Figure S5 and Figure 2 show that crystallization of the amorphous $\mathrm{IrO}_{x}$ phase initially present in the commercial $\mathrm{IrO}_{2}$ comm. triggers a drastic drop in OER mass activity (see $j_{\text {mass }}$ values for $\mathrm{IrO}_{2}$ comm., $\mathrm{IrO}_{2}$ comm. $-450^{\circ} \mathrm{C}$ and $\mathrm{IrO}_{2}$ comm. $-800^{\circ} \mathrm{C}$ ), which is in line with former findings. ${ }^{26-27}$ The same observation can be made for the unsupported porous $\mathrm{IrO}_{\mathrm{x}}$ particles: the gradual formation of the tetragonal structure and the associated transformation of $\operatorname{Ir}(0)$ and $\operatorname{Ir}(+\mathrm{III})$ into $\operatorname{Ir}$ (+IV) species at $T>400{ }^{\circ} \mathrm{C}$ (Figure S2 and Figure S5) decrease both the mass-normalized and the charge-normalized OER activity. In the paper introducing this class of catalytic materials, Faustini et al. ${ }^{25}$ reported that needle-shaped $\mathrm{IrO}_{2}$ crystallites first form on the surface of the porous $\mathrm{IrO}_{\mathrm{x}}$ particles during the thermal annealing process (see also Figure S1). The size of these crystallites then increases with increasing annealing temperature, eventually leading to the collapse of the porous structure at $T=800{ }^{\circ} \mathrm{C}$, and resulting in 7-fold and 40-fold drops in chargenormalized and mass-normalized OER activities, respectively, compared to the mother porous $\mathrm{IrO}_{\mathrm{x}}-400^{\circ} \mathrm{C}$ catalyst. 

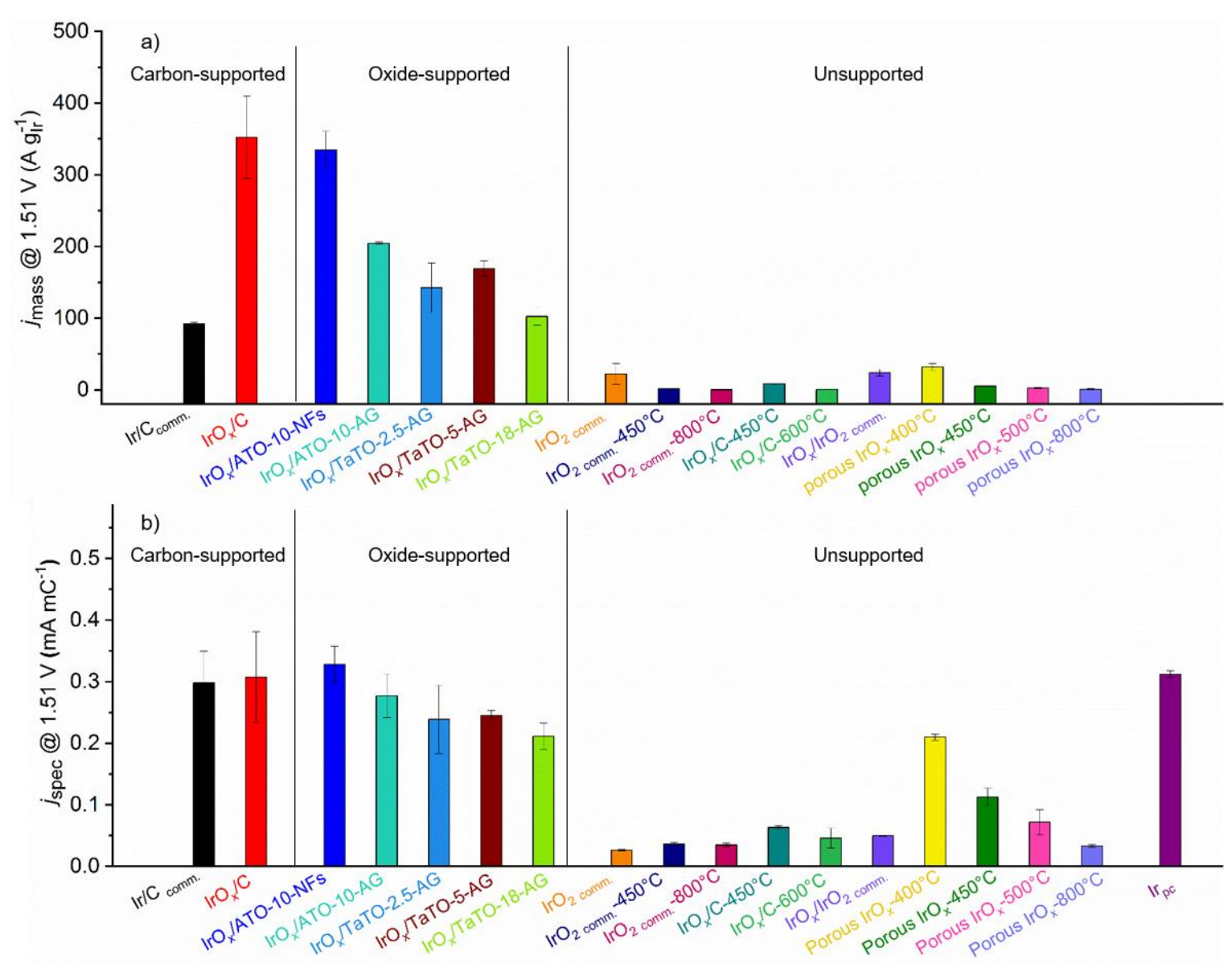

Figure 2. Initial (a) Ir mass-normalized and (b) charge-normalized OER activities measured at $1.51 \mathrm{~V} v s$. RHE for the various catalysts used in this study. The charge in (b) was calculated by integration of the base voltammograms in the potential region $0.4-1.4 \mathrm{~V} v$ s. RHE (anodic potential sweep). All curves were recorded in $0.05 \mathrm{M} \mathrm{H}_{2} \mathrm{SO}_{4}$ at $T=25{ }^{\circ} \mathrm{C}$. The error bars correspond to the standard deviation calculated from at least two independent measurements.

Morphological and structural changes of supported and unsupported IrOx nanocatalysts in OER conditions

The results from this library of materials thus confirm that mixed Ir oxidation states, specific to $\mathrm{IrO}_{\mathrm{x}} \mathrm{NPs}$ produced by the polyol route, lead to enhanced charge-normalized OER activity. Combined with the increase of the ASD value arising from a greater dispersion (ratio of the number 
of surface atoms/total number of atoms), this enhancement is even more obvious from the massnormalized OER activity point of view. However, recent insights from ICP-MS, on-line electrochemical mass spectrometry (OLEMS) and electrochemistry have shown that Ir atoms with oxidation degree $<4$ are not stable over the long term. ${ }^{28-31}$ By combining atom-probe tomography and isotope labelling, Kasian et al. ${ }^{29}$ showed that oxygen atoms in the near-surface region of amorphous $\mathrm{IrO}_{\mathrm{x}}$ films participate in the formation of molecular oxygen and accelerate the dissolution of the Ir atoms. To determine the benefits and limitations of the unsupported and supported $\mathrm{IrO}_{\mathrm{x}}$ catalysts, a given current density of $500 \mathrm{~A} \mathrm{~g}^{-1} \mathrm{Ir}$ (i.e. $10 \mathrm{~mA} \mathrm{~cm}^{-2}$ geo for the carbon and metal oxide supported materials, $\mathrm{IrO}_{2}$ comm. and $\mathrm{IrO}_{x} / \mathrm{IrO}_{2}$ comm. catalysts and $25 \mathrm{~mA} \mathrm{~cm}^{-2}$ geo for the unsupported materials) was applied until the voltage reached $2.0 \mathrm{~V}$ vs. RHE (examples of galvanostatic curves measured at $T=80{ }^{\circ} \mathrm{C}$ may be found in Figure S6). TEM images of the various nanocatalysts before and after the galvanostatic AST are displayed in Figure 3. Clear detachment of the $\mathrm{IrO}_{\mathrm{x}} \mathrm{NPs}$ is visible for the electrocatalysts supported on high-surface area carbon ( $\mathrm{Ir} / \mathrm{C}$ comm. and $\left.\mathrm{IrO}_{\mathrm{x}} / \mathrm{C}\right)$, confirming that carbon supports corrode in OER conditions. ${ }^{16}$ The detachment of $\mathrm{IrO}_{x}$ NPs was less pronounced from doped $\mathrm{SnO}_{2}$ supports, whatever their morphology (AG or NFs). However, former in situ ICP-MS results have shown that both Sn and the doping element leach out from doped $\mathrm{SnO}_{2}$ supports in OER conditions. ${ }^{16,32}$ Dissolution of the doping element leads to a decrease in the electronic conductivity of the $\mathrm{SnO}_{2}$ support and, ultimately, results in electrically disconnected $\mathrm{IrO}_{\mathrm{x}}$ NPs. In contrast, no or mild morphological changes were observed for the unsupported $\mathrm{IrO}_{\mathrm{x}}$ electrocatalysts. For example, IL-TEM images recorded on the most active porous electrocatalysts (porous $\mathrm{IrO}_{\mathrm{x}}-400^{\circ} \mathrm{C}$ and porous $\mathrm{IrO}-450^{\circ} \mathrm{C}$ ) revealed no change in morphology after 200 potential cycles between $1.20<E<1.60 \mathrm{~V} v s$. RHE at $T=60^{\circ} \mathrm{C}$ (Figure $\mathbf{S 7}$ and Figure S8). 


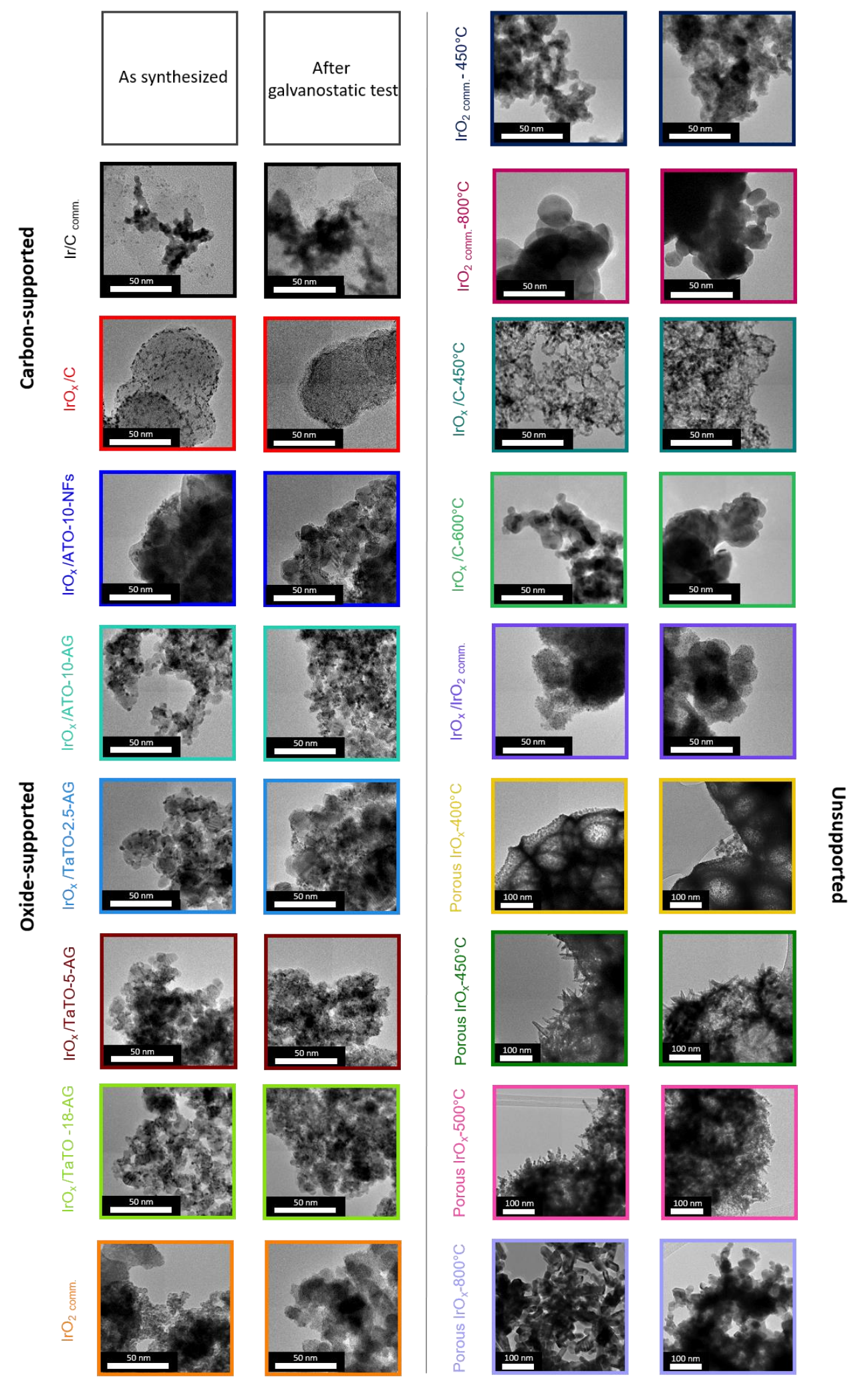

Figure 3. Transmission electron microscopy images of the electrocatalysts before/after the AST (Ar-saturated $0.05 \mathrm{M} \mathrm{H}_{2} \mathrm{SO}_{4}, j=10 \mathrm{~mA} \mathrm{~cm}^{-2}$ geo, $T=80^{\circ} \mathrm{C}, U_{\text {cut-off }}=2 \mathrm{~V} v s . \mathrm{RHE}$ ). 
Determination of S-number values for supported and unsupported Ir $O_{x}$ catalysts

Different metrics can be used to compare the OER activity and the stability of the different $\mathrm{IrO}_{\mathrm{x}}$ based catalysts. In Figure 4, we display the relationship between the initial OER activity of the materials and the duration of the galvanostatic AST, i.e. the time required before reaching the cutoff voltage. Clearly, the most efficient catalysts were also the most robust during the AST, however, does this make them the most stable materials? This issue has been heavily debated in the literature but is in the process of being resolved. Indeed, although initially proposed as a criterion of stability, ${ }^{18,33-37}$ the time required to reach the cut-off voltage in in fact poorly related to the stability of the material. Firstly, because at a constant current, the most active OER catalysts operate under less oxidizing conditions than the least active ones (assuming Tafel kinetics). Indeed, the imposed current is distributed between the different catalytic sites and according to their TOF (Equation 1). The lower OER activity/stability of a given catalytic material thus either stems from its low density of catalytic sites (ASD) or from its low number of electrons transferred per site per second (TOF). Accordingly, Figure S6 shows that the potential always exceeded 1.6 V vs. RHE and that the time required to reach the cut-off voltage was always less for the unsupported $\mathrm{IrO}_{\mathrm{x}}$ catalysts during the galvanostatic AST, especially for those that were thermally-annealed. In contrast, the catalysts featuring a high ASD (e.g. non-annealed supported $\mathrm{IrO}_{\mathrm{x}}$ nanocatalysts) or those which were intrinsically very active towards the OER (e.g. anodically formed Ir oxide on thin-films or single crystals ${ }^{15,38}$ ) electrocatalysed the OER at lower overpotential, and best performed during the galvanostatic AST. A second reason to not consider the time required to reach the cut-off voltage as a criterion of stability has been evoked by Geiger et al. ${ }^{39}$. These authors proposed that the abrupt and rapid increase in potential is related to the passivation of the backing 
electrode and the associated increase in contact resistance with the catalyst. However, the same type of potential-time profiles has been observed by El-Sayed et al. ${ }^{40}$ on gold backing electrode, thus raising doubts on this hypothesis. The physical detachment of the thin-film electrode is also excluded, as revealed by optical images taken before/after the galvanostatic AST (Figure S9 and Figure S10). Other groups suggested that the progressive loss/deactivation of the most active OER sites (in particular $\operatorname{Ir}(\mathrm{V})=\mathrm{O}$ species capable of forming $\mathrm{O}-\mathrm{O}$ bonds ${ }^{41-42}$ ) accounts for the decay in performance. However, although all these hypotheses are scientifically sound, they do not account for the sudden potential increase observed at the end of the galvanostatic AST. According to ElSayed et al. ${ }^{40}$, these are the $\mathrm{O}_{2}$ bubbles generated during the galvanostatic AST, which cause the abrupt potential increase. In this frame, the nanoscopic and microscopic $\mathrm{O}_{2}$ bubbles forming in the thin-film electrode progressively block some catalytic sites, leading to an increase in current (and thus in potential according to Tafel kinetics) on the catalytic sites that are not limited by masstransport, and the sudden potential increase simply translates the autocatalytic character of the process. The fact that the best performing nanocatalysts in Figure $\mathbf{4}$ are all supported onto high surface area, large pore volume carbon black $\left(\mathrm{IrO}_{x} / \mathrm{C}\right)$ aerogels $\left(\mathrm{IrO}_{\mathrm{x}} / \mathrm{ATO}-10-\mathrm{AG}, \mathrm{IrO}_{\mathrm{x}} / \mathrm{TaTO}-\right.$ 2.5-AG, IrOx-TaTO5.0, $\left.\mathrm{IrO}_{\mathrm{x}} / \mathrm{TaTO}-18-\mathrm{AG}\right)$ or nanofibers ( $\mathrm{IrO}_{\mathrm{x}} / \mathrm{ATO}-10-\mathrm{NFs}$ ) further supports the hypothesis of El-Sayed et al. ${ }^{40}$. Decreasing values of $S$-number as a function of the Ir loading is another proof for fast poisoning by $\mathrm{O}_{2}$ bubbles during the galvanostatic AST. This trend was more marked for the unsupported catalysts and is exemplified in Figure $\mathbf{S 1 1}$ for porous $\mathrm{IrO}_{\mathrm{x}}-450^{\circ} \mathrm{C}$. In conclusion, because multiple processes occur during the experiment, a galvanostatic AST is not best suited to assess the stability of a given OER catalyst. Note however that study of degradation mechanism/kinetics of Ir dissolution was not the objective of this study: rather, we strive to gain 
insights into the best compromise between OER activity and stability for the various supported and unsupported $\mathrm{IrO}_{\mathrm{x}}$ catalysts.

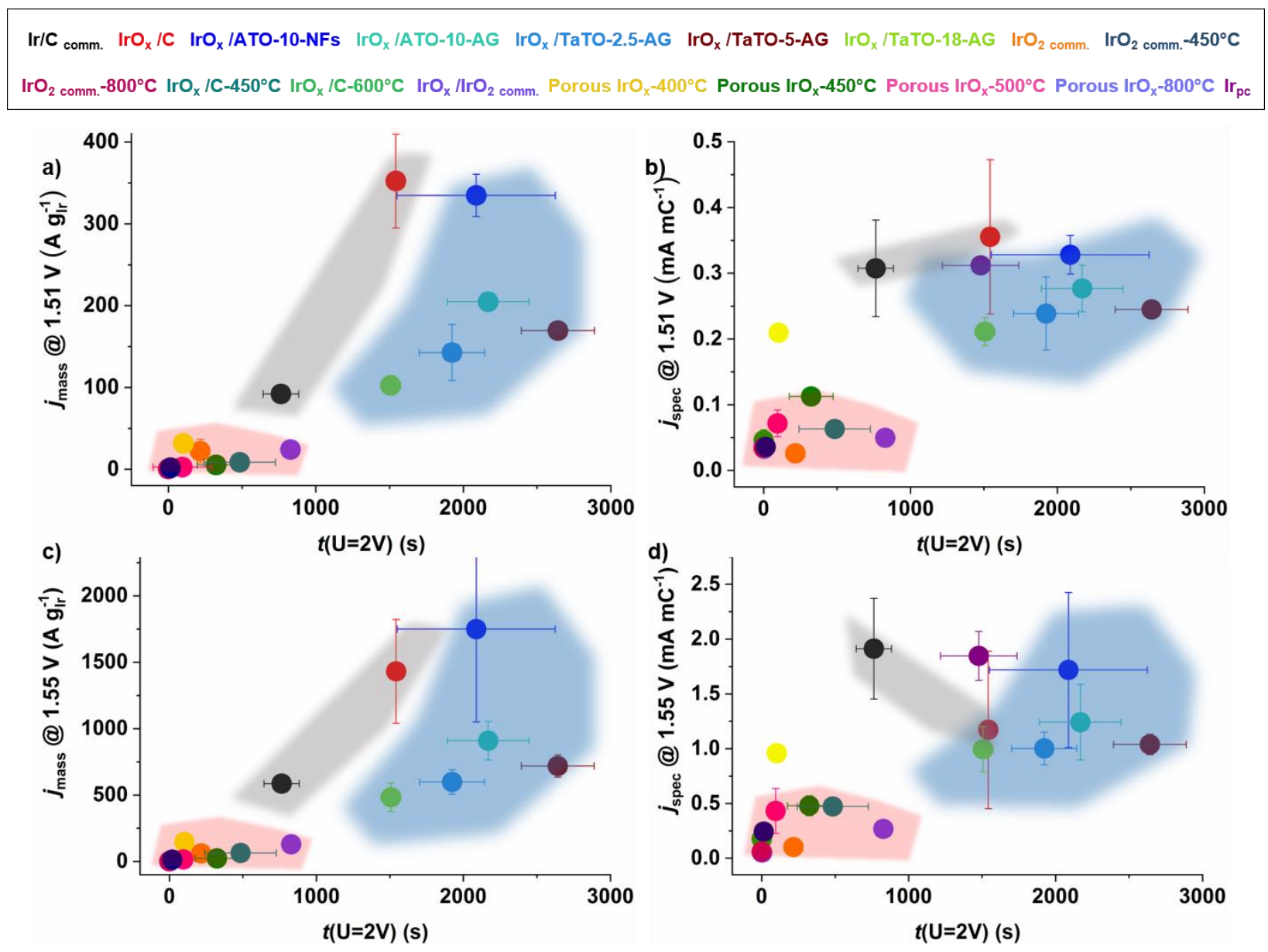

Figure 4. Initial mass-normalized OER activity at a) $1.51 \mathrm{~V} v s$. RHE and c) $1.55 \mathrm{~V} v s$. RHE, and initial charge-normalized OER activity at b) $1.51 \mathrm{~V} v s$. RHE and d) $1.55 \mathrm{~V} v s$. RHE for the electrocatalysts investigated in this study as a function of the duration of the galvanostatic AST. The OER activities were determined from polarization curves $\left(v=5 \mathrm{mV} \mathrm{s}^{-1}, 25{ }^{\circ} \mathrm{C}\right.$, Ar-saturated $0.05 \mathrm{M} \mathrm{H}_{2} \mathrm{SO}_{4}$ ) and the galvanostatic AST was performed at $j=10 \mathrm{~mA} \mathrm{~cm}{ }^{-2}$ geo, $T=80{ }^{\circ} \mathrm{C}, U_{\text {cut-off }}$ $=2 \mathrm{~V} v s . \mathrm{RHE}$ in Ar-saturated $0.05 \mathrm{M} \mathrm{H}_{2} \mathrm{SO}_{4}$. Coloured regions are guides to the eye to distinguish unsupported catalysts (in pink), and carbon- (in grey) or metal oxide-supported (in blue) catalysts. 
To gain a better understanding of the correlations between OER activity and stability, Kim et al. ${ }^{43}$ and Geiger et al. ${ }^{29}$ recently introduced the Activity-Stability Factor (ASF) and the $S$-number, respectively. Kim et al. ${ }^{43}$ defined the ASF as the ratio between the OER current and the equivalent metal dissolution current estimated from ICP-MS analyses. We note that this metric requires knowledge of the number of electrons exchanged during the dissolution of the $\mathrm{IrO}_{\mathrm{x}} \mathrm{NPs}$ and the catalytic supports. Given multiple Ir oxidation states in the $\mathrm{IrO}_{\mathrm{x}} \mathrm{NPs}$ and various dissolution routes for the catalytic supports (including chemical dissolution e.g. for $\mathrm{SnO}_{2}$-based supports), we took the lead not to use it. Rather, we used the $S$-number defined by Geiger et al. ${ }^{29}$ as the ratio between the number of moles of oxygen produced by the OER and the number of moles of Ir dissolved during water electrolysis. The authors estimated the number of moles of evolved oxygen by integrating the current ( $i$ in A) during the potential/current hold (Equation 2):

$$
n_{O_{2}}=\frac{1}{z F} \int i(t) d t
$$

With $z$ the number of moles of electrons transferred during the OER $(z=4), F$ the Faraday constant (in A s mol${ }^{-1}$ ), and $t$ the duration of the galvanostatic AST (in seconds). Strictly speaking, the current recorded during the current hold is the sum of the OER current, the $\mathrm{IrO}_{\mathrm{x}} \mathrm{NPs}$ dissolution current and the support dissolution current. However, as we will see below, the dissolution currents are negligible over OER currents, hence $i$ can be approximated as the OER current.

In turn, the number of moles of dissolved Ir can be determined from the Ir concentration ([Ir] in $\left.\mathrm{g} \mathrm{L}^{-1}\right)$ measured by ICP-MS (Equation 3): 
$n_{I r}=\frac{[I r] \times V}{M_{\text {Ir }}}$

With $V$ the volume of electrolyte in the anodic compartment (in L) and MIr the molar mass of Ir $\left(192.17 \mathrm{~g} \mathrm{~mol}^{-1}\right)$.

The experimental trends, represented in Figure 5, indicate that the unsupported porous $\operatorname{IrO}_{\mathrm{x}}$ catalyst thermally-annealed at $450{ }^{\circ} \mathrm{C}$ offers the best compromise between high OER activity and high stability ( $S$-number value $\sim 320,000$ ), with a 6-fold enhancement over the $S$-number value of reference $\mathrm{IrO}_{2}$ comm. ( 51,000, see values in Table S2). To the best of our knowledge, this is the first time that $S$-number values exceeding that of commercial $\mathrm{IrO}_{2}$ are reported. This result implies that, the mass of Ir introduced at the PEMWE anode could be reduced by a factor of 6 for the same lifespan (investment cost) or that it could significantly decrease the electrical consumption for the same Ir loading (operational cost).

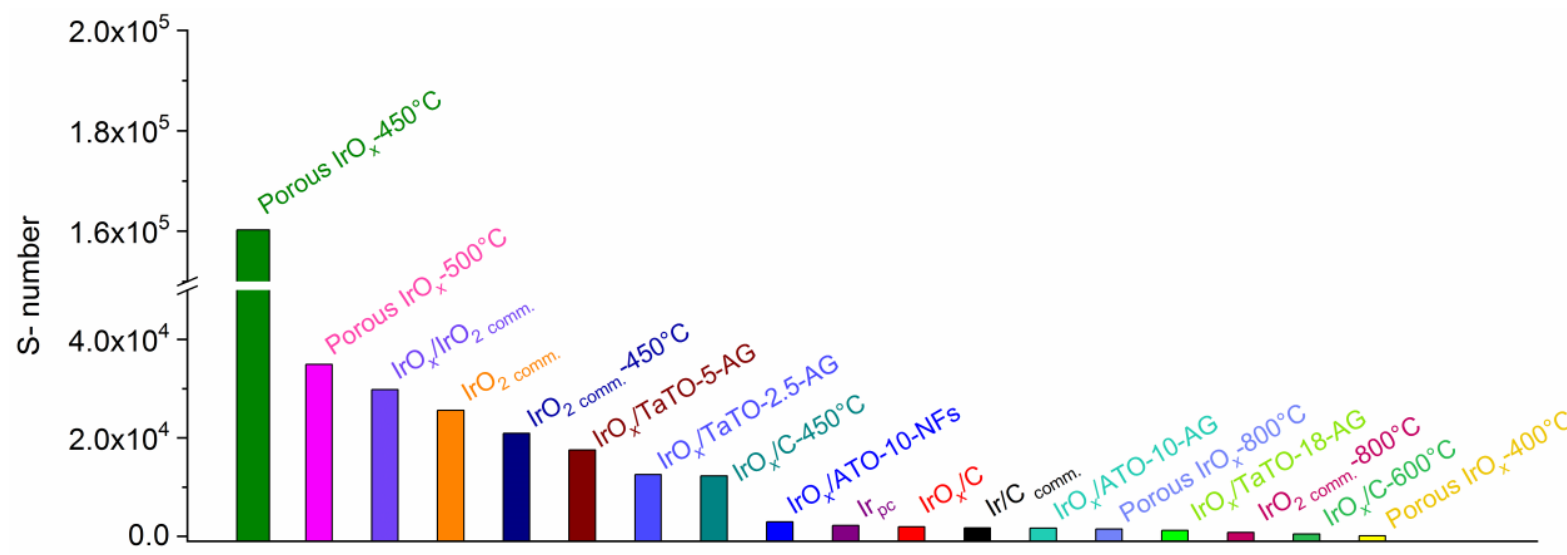

Figure 5. $S$-number values calculated for all the electrocatalysts during a galvanostatic AST performed in Ar-saturated $0.05 \mathrm{M} \mathrm{H}_{2} \mathrm{SO}_{4}$ at $j=10 \mathrm{~mA} \mathrm{~cm}^{-2}$ geo, $T=80{ }^{\circ} \mathrm{C}, U_{\text {cut-off }}=2 \mathrm{~V} v s . \mathrm{RHE}$. 
Some supported $\mathrm{IrO}_{\mathrm{x}}$ nanocatalysts revealed intermediate $S$-number values. For example, as expected, doped $\mathrm{SnO}_{2}$ supports proved to be more robust than high-surface-area carbon blacks, the $S$-number values varying as: $\mathrm{IrO}_{\mathrm{x}} / \mathrm{TaTO}-5-\mathrm{AG}>\mathrm{IrO}_{\mathrm{x}} / \mathrm{TaTO}-2.5-\mathrm{AG} \sim \mathrm{IrO}_{\mathrm{x}} / \mathrm{C}-450^{\circ} \mathrm{C}>>$ $\mathrm{IrO}_{\mathrm{x}} / \mathrm{ATO}-10-\mathrm{NFs}>\mathrm{IrO}_{\mathrm{x}} / \mathrm{C}>\mathrm{Ir} / \mathrm{C}$ comm. $>\mathrm{IrO}_{\mathrm{x}} / \mathrm{ATO}-10-\mathrm{AG}>\mathrm{IrO}_{\mathrm{x}} / \mathrm{TaTO}-18-\mathrm{AG}$. These results, obtained ex situ in a H-cell with separated anodic and cathodic compartments, agree with those reported in our last in situ flow cell ICP-MS study (see Ref. ${ }^{16}$ and Figure S12), and demonstrate that ATO-10 (both in AG and NF forms), high-surface area carbon blacks and TaTO-18 are unstable in OER conditions. In agreement with the TEM micrographs displayed in Figure 3, the drop of the OER performance is likely due to the rapid detachment of $\mathrm{IrO}_{\mathrm{x}} \mathrm{NPs}$ from their supports, leading to a loss of electrochemically active surface area, and thus a rapid increase in the OER overpotential up to the cut-off voltage. The instability of ATO supports in high potential conditions has been ascribed to the preferential leaching of $\mathrm{Sb}$ atoms segregated at their surface. ${ }^{16,32,44-47 .}$ However, such issue can be overcome by using tantalum as doping agent: indeed, $\mathrm{IrO}_{\mathrm{x}} / \mathrm{TaTO}$-2.5$\mathrm{AG}$ and $\left.\mathrm{IrO}_{\mathrm{x}} / \mathrm{TaTO}-5-\mathrm{AG}\right)$ revealed a promising strategy to enhance the $S$-number values $(25,000$ $<S$-number $<35,000)$. Using ICP-MS and scanning-transmission electron microscopy coupled with X-ray energy dispersive spectroscopy imaging, we recently showed that TaTO supports form a stable $\mathrm{Ta}_{2} \mathrm{O}_{5}$ shell covering the mother TaTO support in OER conditions, thus slowing down the dissolution rate of $\mathrm{Sn}$ atoms in the acidic electrolyte. ${ }^{16}$ The Ta concentration proved key to achieve this core@shell structure. For example, on TaTO-2.5, there is a risk of detachment of $\mathrm{IrO}_{\mathrm{x}}$ NPs before the protective $\mathrm{Ta}_{2} \mathrm{O}_{5}$ shell is formed. The high Ta doping concentrations are not recommended either because they lead to low electronic conductivity and separated $\mathrm{SnO}_{2}$ and $\mathrm{Ta}_{2} \mathrm{O}_{5}$ rich domains. A Ta concentration of 5 at. $\%$ in the $\mathrm{SnO}_{2}$ support proved optimal from in 
situ ICP-MS results, and this behavior is confirmed ex situ in Figure 5. It is also interesting to note that intermediate $S$-number values were obtained for the thermally-annealed $\mathrm{IrO}_{\mathrm{x}} / \mathrm{C}-450^{\circ} \mathrm{C}$ electrocatalyst. This material belongs to the unsupported catalyst category; however, its original nanostructure was partially preserved during the combustion of the carbon black support (Figure S1); resulting in high surface area, low OER overpotential, and better resistance to Ir dissolution than the raw material. In fact, the effect of the thermal annealing is subtle and is best illustrated by the porous $\mathrm{IrO}_{\mathrm{x}}$ samples. Indeed, Faustini et al. ${ }^{25}$, showed that Ir surface atoms in porous $\mathrm{IrO}_{\mathrm{x}}-$ $400^{\circ} \mathrm{C}$ feature $\operatorname{Ir}(0), \operatorname{Ir}(+\mathrm{III})$, and $\operatorname{Ir}(+\mathrm{IV})$ species and poorly-ordered tetragonal $\mathrm{IrO}_{2}$ structure (and this is confirmed by Figure S5 and Figure S2, respectively). The $\operatorname{Ir}(+\mathrm{IV})$ oxidation state progressively becomes predominant during the thermal annealing (see X-ray photoelectron spectra of porous $\mathrm{IrO}_{\mathrm{x}}-450^{\circ} \mathrm{C}$, porous $\mathrm{IrO}_{\mathrm{x}}-500^{\circ} \mathrm{C}$ and porous $\mathrm{IrO}_{\mathrm{x}}-800^{\circ} \mathrm{C}$ in $\mathrm{Ref}^{25}$ ), leading to a decrease of the charge-normalized OER activity that is easy to rationalize based on the 6-fold drop in intrinsic OER activity for $\operatorname{Ir}(+\mathrm{IV})$ species over $\operatorname{Ir}(+\mathrm{III})$ species reported by Claudel et al. ${ }^{15}$. Importantly, oxidation of Ir surface atoms revealed beneficial to the $S$-number value as long as it does not induce crystallite growth, the best compromise between OER activity and stability being found for porous $\mathrm{IrO}_{\mathrm{x}}-450^{\circ} \mathrm{C}$. This result is at variance with those obtained by Geiger et al. ${ }^{48}$ on metallic Ir and electrochemically prepared porous hydrous $\mathrm{IrO}_{\mathrm{x}}$ films but the conclusions of these two studies must not be opposed. Rather, they demonstrate that the conclusions obtained on extended surfaces are not necessarily transferable to nano- and micro-materials. Indeed, the Ir oxidation state and the $\mathrm{IrO}_{2}$ crystallite size (two key parameters that determine the OER activity and the stability of a given catalytic material) strongly depend on the initial oxidation state of the Ir atoms, the initial $\mathrm{Ir} / \mathrm{IrO}_{\mathrm{x}}$ crystallite size, and the oxygen concentration (oxygen $v s$. air), the duration and the temperature of the thermal annealing step, these being different in Geiger's study 
and in this work. Secondly, nanomaterials are, in many aspects, different from that of well-defined single crystals, polycrystalline electrode or thin films. In particular, whereas thermal annealing under oxygen leads to an increase in the average $\mathrm{Ir}$ oxidation state and in the $\mathrm{IrO}_{2}$ crystallize size for all types of materials, the associated effect on the ASD (or electrochemically active surface area) and on the mass activity towards the OER will be extremely marked for nanomaterials, less marked for micro-materials and practically conveys no meaning for extended surfaces. A major hurdle to reach $S$-number values of commercial $\mathrm{IrO}_{2}$ particles on nano- and micro-materials then consists to finely tune the thermal annealing conditions to oxidize Ir surface atoms, while minimize the increase in crystallite size and thus maintain high OER mass activity.

\section{CONCLUSION}

In conclusion, using a library of 18 supported and unsupported materials, we shed light on the chemical, structural and morphological characteristics that confer electrocatalytic activity and stability to oxygen evolution reaction catalysts. Our results showed that supported nanocatalysts are extremely active towards the OER because they feature mixed Ir oxidation states and a high density of active sites (small crystallite/particle size). The lack of robustness of their supports, however, prevents the nanocatalysts from sustaining this high OER activity. TaTO supports, less subject to leaching of the doping element than ATO supports, are clearly the most interesting ones from a stability perspective. However, the Ta doping concentration should be finely controlled. ${ }^{16}$ In contrast, unsupported materials guarantee long-term OER activity but they suffer from an insufficient density of catalytic sites. Coupled electrochemistry and metal dissolution measurements evidenced that thermal annealing at $450{ }^{\circ} \mathrm{C}$ offers the best compromise between 
initial and long-term OER activities. Our findings thus lay the ground for a rational approach towards sustainable OER activity in PEM water electrolyzers.

\section{AUTHOR INFORMATION}

\section{Corresponding Authors}

* E-mail address for F.M: frederic.maillard@lepmi.grenoble-inp.fr

\section{Author Contributions}

F.C., C.D.F. and F.M., conceived the experiments, wrote and edited the first version of the manuscript. C.D.F., F.C., R.C, S.A., L.D. and F.M analyzed, interpreted and discussed the results and drew conclusions. C.D.F, F.C., R.C., I.J-M., L.S-H., M.F., J.P. and B.G. designed and synthesized the materials. V.M. and S.A. conducted and analyzed ICP-MS measurements. V.M. and K.K. performed and fitted the XPS measurements. L.D. and F.C performed TEM and IL-TEM measurements. T.E. performed XRD measurements. C.D.F. and F.M. performed the electrochemistry experiments and analyzed the data. All authors revised and approved the final version of this manuscript.

$\gamma$ These authors contributed equally.

$\alpha$ This manuscript is dedicated to Dr. Camila Daiane Ferreira da Silva who suddenly passed away in December 2020.

\section{CONFLICT OF INTEREST}

The authors declare no competing financial interest.

\section{ASSOCIATED CONTENT}




\section{Supporting Information.}

The Supporting Information is available free of charge via the Internet at http://pubs.acs.org. It comprises:

- Material and Methods;

- Transmission electron microscopy images, Ir mass-normalized polarization curves and base cyclic voltammograms recorded on the catalysts used in this study;

- X-ray diffractograms of all catalysts used in this study;

- X-ray diffractograms of $\mathrm{IrO}_{2}$ comm. upon thermal annealing from 27 to $800^{\circ} \mathrm{C}$;

- Initial OER activities at $E=1.55 \mathrm{~V} v s$. RHE for all catalysts used in this study;

- X-ray photoelectron spectra of porous $\mathrm{IrO}_{\mathrm{x}}-400^{\circ} \mathrm{C}$, porous $\mathrm{IrO}_{\mathrm{x}}-450^{\circ} \mathrm{C}, \mathrm{IrO} \mathrm{x}_{\mathrm{x}} / \mathrm{C}-450^{\circ} \mathrm{C}$ and $\mathrm{IrO}_{2} \mathrm{comm}-450^{\circ} \mathrm{C}$;

- Galvanostatic polarization at $10 \mathrm{~mA} \mathrm{~cm}^{-2}$ geo of Ir-based electrocatalysts;

- Identical-location transmission electron microscopy images obtained on as-synthesized porous $\mathrm{IrO}_{\mathrm{x}}-400^{\circ} \mathrm{C}$ and porous $\mathrm{IrO}_{\mathrm{x}}-450^{\circ} \mathrm{C}$ during electrochemical conditioning and after 200 potential cycles between $1.20<E<1.60 \mathrm{~V} v s$. RHE at $T=60^{\circ} \mathrm{C}$;

- Optical micrographs of an $\mathrm{IrO}_{x} /$ ATO-10-NFs thin film before and after the galvanostatic test and respective cyclic voltammograms and OER polarization curves;

- Cyclic voltammograms and OER polarization curves of an $\mathrm{IrO}_{2}$ comm $-450^{\circ} \mathrm{C}$ thin film before and after the galvanostatic test;

- Calculated $S$-number values for Porous $\mathrm{IrO}_{\mathrm{x}}-450^{\circ} \mathrm{C}$ as a function of the Ir loading.

- Calculated $S$-number values at $E=1.6 \mathrm{~V} v s$. RHE for supported $\mathrm{IrO}_{\mathrm{x}}$ nanoparticles and commercial $\mathrm{IrO}_{2}$ comm catalysts;

- Structural and substructural properties of some supported $\mathrm{IrO}_{\mathrm{x}}$ catalysts; 
- $\quad S$-number values calculated for all electrocatalysts during the galvanostatic AST;

- References.

\section{ACKNOWLEDGEMENTS}

This work was performed within the framework of the Centre of Excellence of Multifunctional Architectured Materials "CEMAM" (ANR-10-LABX-44-01). The French National Research Agency (MOISE project, ANR-17-CE05-0033) financially supported this research). The authors acknowledge the financial support of the Fonds Inkermann, under the ageis of the Fondation de France. F.C. acknowledges the Region Auvergne Rhône-Alpes for funding his Ph.D. thesis in the frame of the ARC Energies program (ARC $2016 \mathrm{n}^{\circ} 04$ ADR). C.D.F. and F.H.B.L. acknowledge the Coordenação de Aperfeiçoamento de Pessoal de Nível Superior (CAPES), CAPES/COFECUB program (process numbers: 88887.361310/2019-00 and Ph-C 914/18) for funding C.D.F.'s oneyear research stay at LEPMI, the São Paulo Research Foundation (FAPESP - process number: 2019/22183-6), and Conselho Nacional de Desenvolvimento Científico e Tecnológico (CNPq process number 309465/2019-2) for financial support. S. C. thanks the French IUF for its support.

\section{REFERENCES}

1. BP Statistical Review of World Energy. https://www.bp.com/statisticalreview (accessed 2021-01-25).

2. NEF, B. Battery Pack Prices Fall as Market Ramps up with Market Average at $\$ 156 / \mathrm{Kwh}$ in 2019. https://about.bnef.com/blog/battery-pack-prices-fall-as-market-ramps-up-with-marketaverage-at-156-kwh-in-2019/ (accessed 2020-10-23). 
3. Anderson, G. C.; Pivovar, B. S.; Alia, S. M., Establishing Performance Baselines for the Oxygen Evolution Reaction in Alkaline Electrolytes. J. Electrochem. Soc. 2020, 167, 044503.

4. Schmidt, O.; Gambhir, A.; Staffell, I.; Hawkes, A.; Nelson, J.; Few, S., Future Cost and Performance of Water Electrolysis: An Expert Elicitation Study. Int. J. Hydrogen Energy. 2017, $42,30470-30492$.

5. Agency, I. R. E., Hydrogen from Renewable Power: Technology Outlook for the Energy Transition. Abu Dhabi, 2018.

6. Babic, U.; Suermann, M.; Buechi, F. N.; Gubler, L.; Schmidt, T. J., Review-Identifying Critical Gaps for Polymer Electrolyte Water Electrolysis Development. J. Electrochem. Soc. 2017, 164, F387-F399.

7. Mitchell, R. H.; Keays, R. R., Abundance and Distribution of Gold, Palladium and Iridium in Some Spinel and Garnet Iherzolites- Implications for the Nature and Origin of Precious MetalRich Intergranular Omonents in the Upper Mantle. Geochim. Cosmochim. Acta. 1981, 45, 24252442.

8. Chang, S. H.; Connell, J. G.; Danilovic, N.; Subbaraman, R.; Chang, K. C.; Stamenkovic, V. R.; Markovic, N. M., Activity-Stability Relationship in the Surface Electrochemistry of the Oxygen Evolution Reaction. Faraday Discuss. 2014, 176, 125-133.

9. Danilovic, N.; Subbaraman, R.; Chang, K. C.; Chang, S. H.; Kang, Y. J.; Snyder, J.; Paulikas, A. P.; Strmcnik, D.; Kim, Y. T.; Myers, D.; Stamenkovic, V. R.; Markovic, N. M., Activity-Stability Trends for the Oxygen Evolution Reaction on Monometallic Oxides in Acidic Environments. J. Phys. Chem. Lett. 2014, 5, 2474-2478.

10. Cherevko, S.; Geiger, S.; Kasian, O.; Kulyk, N.; Grote, J.-P.; Savan, A.; Shrestha, B. R.; Merzlikin, S.; Breitbach, B.; Ludwig, A.; Mayrhofer, K. J. J., Oxygen and Hydrogen Evolution 
Reactions on $\mathrm{Ru}, \mathrm{RuO}_{2}$, Ir, and $\mathrm{IrO}_{2}$ Thin Film Electrodes in Acidic and Alkaline Electrolytes: A Comparative Study on Activity and Stability. Catal. Today. 2016, 262, 170-180.

11. Minguzzi, A.; Lugaresi, O.; Achilli, E.; Locatelli, C.; Vertova, A.; Ghigna, P.; Rondinini, S., Observing the Oxidation State Turnover in Heterogeneous Iridium-Based Water Oxidation Catalysts. Chem. Sci. 2014, 5, 3591-3597.

12. Minguzzi, A.; Lugaresi, O.; Locatelli, C.; Rondinini, S.; D'Acapito, F.; Achilli, E.; Ghigna, P., Fixed Energy X-Ray Absorption Voltammetry. Anal. Chem. 2013, 85, 7009-7013.

13. Scohy, M.; Abbou, S.; Martin, V.; Gilles, B.; Sibert, E.; Dubau, L.; Maillard, F., Probing Surface Oxide Formation and Dissolution on/of Ir Single Crystals Via X-Ray Photoelectron Spectroscopy and Inductively Coupled Plasma Mass Spectrometry. ACS Catal. 2019, 9, 98599869.

14. Arminio-Ravelo, J. A.; Jensen, A. W.; Jensen, K. D.; Quinson, J.; Escudero-Escribano, M., Electrolyte Effects on the Electrocatalytic Performance of Iridium-Based Nanoparticles for Oxygen Evolution in Rotating Disc Electrodes. Chemphyschem. 2019, 20, 2956-2963.

15. Claudel, F.; Dubau, L.; Berthomé, G.; Solà-Hernández, L.; Beauger, C.; Piccolo, L.; Maillard, F., Degradation Mechanisms of Oxygen Evolution Reaction Electrocatalysts: A Combined Identical-Location Transmission Electron Microscopy and X-Ray Photoelectron Spectroscopy Study. ACS Catal. 2019, 9, 4688-4698.

16. Abbou, S.; Chattot, R.; Martin, V.; Claudel, F.; Solà-Hernandez, L.; Beauger, C.; Dubau, L.; Maillard, F., Manipulating the Corrosion Resistance of $\mathrm{SnO}_{2}$ Aerogels through Doping for Efficient and Durable Oxygen Evolution Reaction Electrocatalysis in Acidic Media. ACS Catal. 2020, $10,7283-7294$. 
17. Saveleva, V. A.; Wang, L.; Kasian, O.; Batuk, M.; Hadermann, J.; Gallet, J. J.; Bournel, F.; Alonso-Vante, N.; Ozouf, G.; Beauger, C.; Mayrhofer, K. J. J.; Cherevko, S.; Gago, A. S.; Friedrich, K. A.; Zafeiratos, S.; Savinova, E. R., Insight into the Mechanisms of High Activity and Stability of Iridium Supported on Antimony-Doped Tin Oxide Aerogel for Anodes of Proton Exchange Membrane Water Electrolyzers. ACS Catal. 2020, 10, 2508-2516.

18. Oh, H. S.; Nong, H. N.; Reier, T.; Bergmann, A.; Gliech, M.; Ferreira De Araújo, J.; Willinger, E.; Schlögl, R.; Teschner, D.; Strasser, P., Electrochemical Catalyst-Support Effects and Their Stabilizing Role for $\mathrm{IrO}_{\mathrm{x}}$ Nanoparticle Catalysts During the Oxygen Evolution Reaction. J. Am. Chem. Soc. 2016, 138, 12552-12563.

19. Sanchez Casalongue, H. G.; Ng, M. L.; Kaya, S.; Friebel, D.; Ogasawara, H.; Nilsson, A., In Situ Observation of Surface Species on Iridium Oxide Nanoparticles During the Oxygen Evolution Reaction. Angew. Chem. 2014, 53, 7169-72.

20. Kasian, O.; Grote, J. P.; Geiger, S.; Cherevko, S.; Mayrhofer, K. J. J., The Common Intermediates of Oxygen Evolution and Dissolution Reactions During Water Electrolysis on Iridium. Angew. Chem., Int. Ed. Engl. 2018, 57, 2488-2491.

21. Minguzzi, A.; Locatelli, C.; Lugaresi, O.; Achilli, E.; Cappelletti, G.; Scavini, M.; Coduri, M.; Masala, P.; Sacchi, B.; Vertova, A.; Ghigna, P.; Rondinini, S., Easy Accommodation of Different Oxidation States in Iridium Oxide Nanoparticles with Different Hydration Degree as Water Oxidation Electrocatalysts. ACS Catal. 2015, 5, 5104-5115.

22. Kötz, R.; Neff, H.; Stucki, S., Anodic Iridium Oxide Films: XPS-Studies of Oxidation State Changes and $\mathrm{O}_{2}$-Evolution. J. Electrochem. Soc. 1984, 131, 72-77. 
23. Cherevko, S.; Geiger, S.; Kasian, O.; Mingers, A.; Mayrhofer, K. J. J., Oxygen Evolution Activity and Stability of Iridium in Acidic Media. Part 2. - Electrochemically Grown Hydrous Iridium Oxide. J. Electroanal. Chem. 2016, 774, 102-110.

24. Pfeifer, V.; Jones, T. E.; Velasco Velez, J. J.; Arrigo, R.; Piccinin, S.; Havecker, M.; KnopGericke, A.; Schlögl, R., In Situ Observation of Reactive Oxygen Species Forming on OxygenEvolving Iridium Surfaces. Chem. Sci. 2017, 8, 2143-2149.

25. Faustini, M.; Giraud, M.; Jones, D.; Rozière, J.; Dupont, M.; Porter, T. R.; Nowak, S.; Bahri, M.; Ersen, O.; Sanchez, C.; Boissière, C.; Tard, C.; Peron, J., Hierarchically Structured Ultraporous Iridium-Based Materials: A Novel Catalyst Architecture for Proton Exchange Membrane Water Electrolyzers. Adv. Energy Mater. 2018, o, 1802136.

26. Cherevko, S.; Reier, T.; Zeradjanin, A. R.; Pawolek, Z.; Strasser, P.; Mayrhofer, K. J. J., Stability of Nanostructured Iridium Oxide Electrocatalysts During Oxygen Evolution Reaction in Acidic Environment. Electrochem. Com. 2014, 48, 81-85.

27. Reier, T.; Teschner, D.; Lunkenbein, T.; Bergmann, A.; Selve, S.; Kraehnert, R.; Schlögl, R.; Strasser, P., Electrocatalytic Oxygen Evolution on Iridium Oxide: Uncovering CatalystSubstrate Interactions and Active Iridium Oxide Species. J. Electrochem. Soc. 2014, 161, F876F882.

28. Fierro, S.; Nagel, T.; Baltruschat, H.; Comninellis, C., Investigation of the Oxygen Evolution Reaction on $\mathrm{Ti} / \mathrm{IrO}_{2}$ Electrodes Using Isotope Labelling and on-Line Mass Spectrometry. Electrochem. Com. 2007, 9, 1969-1974.

29. Geiger, S.; Kasian, O.; Ledendecker, M.; Pizzutilo, E.; Mingers, A. M.; Fu, W. T.; DiazMorales, O.; Li, Z.; Oellers, T.; Fruchter, L.; Ludwig, A.; Mayrhofer, K. J. J.; Koper, M. T. M.; 
Cherevko, S., The Stability Number as a Metric for Electrocatalyst Stability Benchmarking. Nat. Catal. 2018, 1, 508-515.

30. Grimaud, A.; Demortière, A.; Saubanère, M.; Dachraoui, W.; Duchamp, M.; Doublet, M.L.; Tarascon, J.-M., Activation of Surface Oxygen Sites on an Iridium-Based Model Catalyst for the Oxygen Evolution Reaction. Nature Energy. 2016, 2, 16189.

31. Grimaud, A.; Diaz-Morales, O.; Han, B.; Hong, W. T.; Lee, Y. L.; Giordano, L.; Stoerzinger, K. A.; Koper, M. T. M.; Shao-Horn, Y., Activating Lattice Oxygen Redox Reactions in Metal Oxides to Catalyse Oxygen Evolution. Nat. Chem. 2017, 9, 457-465.

32. Geiger, S.; Kasian, O.; Mingers, A. M.; Mayrhofer, K. J. J.; Cherevko, S., Stability Limits of Tin-Based Electrocatalyst Supports. Sci. Rep. 2017, 7.

33. Oh, H. S.; Nong, H. N.; Reier, T.; Gliech, M.; Strasser, P., Oxide-Supported Ir Nanodendrites with High Activity and Durability for the Oxygen Evolution Reaction in Acid Pem Water Electrolyzers. Chem. Sci. 2015, 6, 3321-3328.

34. Massué, C.; Huang, X.; Tarasov, A.; Ranjan, C.; Cap, S.; Schlögl, R., Microwave-Assisted Synthesis of Stable and Highly Active Ir Oxohydroxides for Electrochemical Oxidation of Water. ChemSusChem. 2017, 10, 1958-1968.

35. Massue, C.; Pfeifer, V.; Huang, X.; Noack, J.; Tarasov, A.; Cap, S.; Schloegl, R., HighPerformance Supported Iridium Oxohydroxide Water Oxidation Electrocatalysts. ChemSusChem. 2017, 10, 1943-1957.

36. McCrory, C. C. L.; Jung, S.; Peters, J. C.; Jaramillo, T. F., Benchmarking Heterogeneous Electrocatalysts for the Oxygen Evolution Reaction. J. Am. Chem. Soc. 2013, 135, 16977-16987. 
37. McCrory, C. C. L.; Jung, S.; Ferrer, I. M.; Chatman, S. M.; Peters, J. C.; Jaramillo, T. F., Benchmarking Hydrogen Evolving Reaction and Oxygen Evolving Reaction Electrocatalysts for Solar Water Splitting Devices. J. Am. Chem. Soc. 2015, 137, 4347-4357.

38. Scohy, M.; Montella, C.; Claudel, F.; Abbou, S.; Dubau, L.; Maillard, F.; Sibert, E.; Sunde, S., Investigating the Oxygen Evolution Reaction on $\operatorname{Ir}(111)$ Electrode in Acidic Medium Using Conventional and Dynamic Electrochemical Impedance Spectroscopy. Electrochim. Acta. 2019, 320.

39. Geiger, S.; Kasian, O.; Mingers, A. M.; Nicley, S. S.; Haenen, K.; Mayrhofer, K. J. J.; Cherevko, S., Catalyst Stability Benchmarking for the Oxygen Evolution Reaction: The Importance of Backing Electrode Material and Dissolution in Accelerated Aging Studies. ChemSusChem. 2017, 10, 4140-4143.

40. El-Sayed, H. A.; Weiss, A.; Olbrich, L. F.; Putro, G. P.; Gasteiger, H. A., OER Catalyst Stability Investigation Using RDE Technique: A Stability Measure or an Artifact? J. Electrochem. Soc. 2019, 166, F458-F464.

41. Tang-Kong, R.; Chidsey, C. E. D.; McIntyre, P. C., Reversible Decay of Oxygen Evolution Activity of Iridium Catalysts. J. Electrochem. Soc. 2019, 166, H712-H717.

42. Tan, X.; Shen, J.; Semagina, N.; Secanell, M., Decoupling Structure-Sensitive Deactivation Mechanisms of $\mathrm{Ir} / \mathrm{IrO}$ E Electrocatalysts toward Oxygen Evolution Reaction. J. Catal. 2019, 371, 57-70.

43. Kim, Y. T.; Lopes, P. P.; Park, S. A.; Lee, A. Y.; Lim, J.; Lee, H.; Back, S.; Jung, Y.; Danilovic, N.; Stamenkovic, V.; Erlebacher, J.; Snyder, J.; Markovic, N. M., Balancing Activity, Stability and Conductivity of Nanoporous Core-Shell Iridium/Iridium Oxide Oxygen Evolution Catalysts. Nat. Commun. 2017, 8, 1449. 
44. Cognard, G.; Ozouf, G.; Beauger, C.; Berthomé, G.; Riassetto, D.; Dubau, L.; Chattot, R.; Chatenet, M.; Maillard, F., Benefits and Limitations of Pt Nanoparticles Supported on Highly Porous Antimony-Doped Tin Dioxide Aerogel as Alternative Cathode Material for ProtonExchange Membrane Fuel Cells. Appl. Catal. B. 2017, 201, 381-390.

45. Cognard, G.; Ozouf, G.; Beauger, C.; Dubau, L.; López-Haro, M.; Chatenet, M.; Maillard, F., Insights into the Stability of Pt Nanoparticles Supported on Antimony-Doped Tin Oxide in Different Potential Ranges. Electrochim. Acta. 2017, 245, 993-1004.

46. Jiménez-Morales, I.; Cavaliere, S.; Dupont, M.; Jones, D.; Rozière, J., On the Stability of Antimony Doped Tin Oxide Supports in Proton Exchange Membrane Fuel Cell and Water Electrolysers. Sustainable Energy \& Fuels. 2019, 3, 1526-1535.

47. da Silva, G. C.; Venturini, S. I.; Zhang, S.; Löffler, M.; Scheu, C.; Mayrhofer, K. J. J.; Ticianelli, E. A.; Cherevko, S., Oxygen Evolution Reaction on Tin Oxides Supported Iridium Catalysts: Do We Need Dopants? ChemElectroChem. 2020, 7, 2330-2339.

48. Geiger, S.; Kasian, O.; Shrestha, B. R.; Mingers, A. M.; Mayrhofer, K. J. J.; Cherevko, S., Activity and Stability of Electrochemically and Thermally Treated Iridium for the Oxygen Evolution Reaction. J. Electrochem. Soc. 2016, 163, F3132-F3138. 